\title{
POTENTIAL INFLUENCE OF A PLANNED LANDFILL ON A HIGH KARST PLATEAU IN SOUTHWESTERN MONTENEGRO TO NEARBY KARSTIC SPRINGS
}

\author{
POTENCIALNI VPLIV NAČRTOVANEGA ODLAGALIŠČA \\ ODPADKOV NA VISOKEM KRASU V JUGOZAHODNI ČRNI GORI \\ NA BLIŽNJE KRAŠKE IZVIRE
}

\author{
Micha HORACEK ${ }^{1,2,}$, Milan RADULOVIC ${ }^{3}$, Dejan JANCIC ${ }^{4}$, Stefan WYHLIDAL ${ }^{5,6}$ \\ \& Golub ĆULAFIĆ7
}

\begin{abstract}
UDC 556.36:551.435.8:628.472.3(497.16) Micha Horacek, Milan Radulovic, Dejan Jancic, Stefan Wyhlidal \& Golub Ćulafić: Potential influence of a planned landfill on a high karst plateau in Southwestern Montenegro to nearby karstic springs

The potential threat of a landfill projected on a high karst plateau in southwest Montenegro is investigated with respect to the subjacent nearby springs. The locality is called Duboki do. As the springs are used for drinking water supply this investigation is urgently needed. For the springs exist two hypotheses concerning their catchment area: I) from the high karst plateau, or II) from a topographically lower area. The stable $\mathrm{H}$ - and Oisotope ratios of water samples from the springs are compared with precipitation isotope data, to reveal the catchment area of the springs. The isotope results indicate that the catchment area of the springs is at higher altitude fitting to, and in good agreement with, winter precipitation from the high karst plateau of the planned land-fill locality.

Keywords: isotope hydrology, hydrogen isotopes, oxygen isotopes, d-excess, catchment area, karst hydrology, precipitation.
\end{abstract}

Izvleček UDK 556.36:551.435.8:628.472.3(497.16) Micha Horacek, Milan Radulovic, Dejan Jancic, Stefan Wyhlidal \& Golub Ćulafić: Potencialni vpliv načrtovanega odlagališča odpadkov na visokem krasu v jugozahodni Črni gori na bližnje kraške izvire

Potencialna grožnja odlagališča odpadkov, načrtovanega na visokem krasu v jugozahodni Črni gori, je bila proučena glede na bližnje nižje ležeče izvire. Lokacija se imenuje Duboki do. Ker se izvirska voda uporablja za oskrbo s pitno vodo, je ta raziskava nujno potrebna. Za izvire obstajata dve hipotezi o njihovem zaledju: I) iz visokega krasa in II) iz topografsko nižjega območja. Razmerja stabilnih izotopov vodika in kisika v vzorcih vode iz izvirov smo primerjali s podatki o izotopski sestavi padavin, da bi razkrili zaledje izvirov. Rezultati izotopov kažejo, da je zaledje izvirov na višji nadmorski višini ter prilagojeno zimskim padavinam - in jih dobro prevaja - iz visokega krasa načrtovane lokacije odlagališča odpadkov.

Ključne besede: izotopska hidrologija, izotopi vodika, izotopi kisika, devterijev presežek, povodje, kraška hidrologija, padavine.

\footnotetext{
${ }^{1}$ Department of Lithospheric Research, Vienna University, Althanstr. 14, A-1090 Vienna, Austria, e-mail: micha.horacek@josephinum.at

2 (further affiliation: BLT Wieselburg, Höhere Bundeslehr- und Forschungsanstalt (HBLFA) Francisco-Josephinum,

Rottenhauserstr. 1, A-3250 Wieselburg, Austria, e-mail: micha.horacek@josephinum.at)

${ }^{3}$ Faculty of Civil Engineering, University of Montenegro, Cetinjski put bb, ME-81000 Podgorica, Montenegro, e-mail: radulovicmilan33@yahoo.com

${ }^{4}$ Center for Eco-Toxicological Research Podgorica, Bulevar Šarla De Gola 2, ME-81000 Podgorica, Montenegro, e-mail: dejan.jancic@ceti.co.me

${ }^{5}$ Austrian Institute of Technology GmbH, Konrad-Lorenz-Str. 24, A-3430 Tulln, Austria, e-mail: Stefan.Wyhlidal@nes.at

${ }^{6}$ Nuclear Engineering Seibersdorf GmbH, Forschungszentrum, A-2444 Seibersdorf, Austria, (present address), e-mail: Stefan.Wyhlidal@nes.at

${ }^{7}$ Institute of Hydrometeorology and Seismology of Montenegro, IV proleterske 19, ME-81000 Podgorica, Montenegro, e-mail: golub.culafic@meteo.co.me

* Corresponding author
}

Received/Prejeto: 6.12.2019 


\section{INTRODUCTION}

Clean groundwater in abundant quantity is one of the most precious resources in any region of the world. Over-use, contamination and changes in the recharge of groundwater bodies have led to water scarcity and difficulties in water availability or quality in many regions of the world. Accumulation of knowledge about the processes in and around the groundwater is essential for the responsible use, exploitation and protection of this resource.

For the purposes of the waste disposal from the territory of the Herceg Novi municipality at the Boka bay, southwestern Montenegro, the construction of the landfill "Duboki do" is planned (Figure 1). The site of the projected landfill is located on the high karst plateau above the Boka bay (Figure 2). The altitude of the landfill location is about 1,050 $\mathrm{m}$ a.s.l. Since the wider high-altitude area is characterized by large amounts of rainfall (mean annual precipitation range from 3,000 to $5,000 \mathrm{~mm}$ (IJC, 2001) and high permeability of the rocks, the region is very rich in groundwater.

The most important groundwater sources in this area are the Opačica spring (about $7 \mathrm{~m}$ a.s.l.), which feeds in the Herceg Novi water-supply system and the Morinj spring (5 $\mathrm{m}$ a.s.l.), which represents a potential source for supplying a part of the territory of Kotor municipality (Radulović, 1995, 2000; Marić, 1997; Dubljević, 2001; Radulović \& Radulović, 2004). Also, there are numerous smaller springs (Dezdarica spring, Česma spring, Bunovići springs and Dragomanovići springs), which are used for the water-supplying of smaller settlements.

The crucial question is whether a leakage of waste water from the projected landfill can pollute the nearby springs (Figure 3), which are located below the high karst plateau near the coast. According to one hypothesis (I), the recharge area of the springs is on the Karst plateau with an average altitude of about 1,100 m a.s.l. (Figure 3), covering the wider area of the proposed landfill location. Another hypothesis (II) claims that the recharge zone of these springs is situated in the background of Morinj bay on a terrain with an average altitude of about $500 \mathrm{~m}$ a.s.l. (Figure 3). These two zones are divided by impervious Flysh sediments, so the main question is whether the water infiltrating the Karst plateau at 1,100 m a.s.l., at the projected locality of the landfill, flows below the Flysch

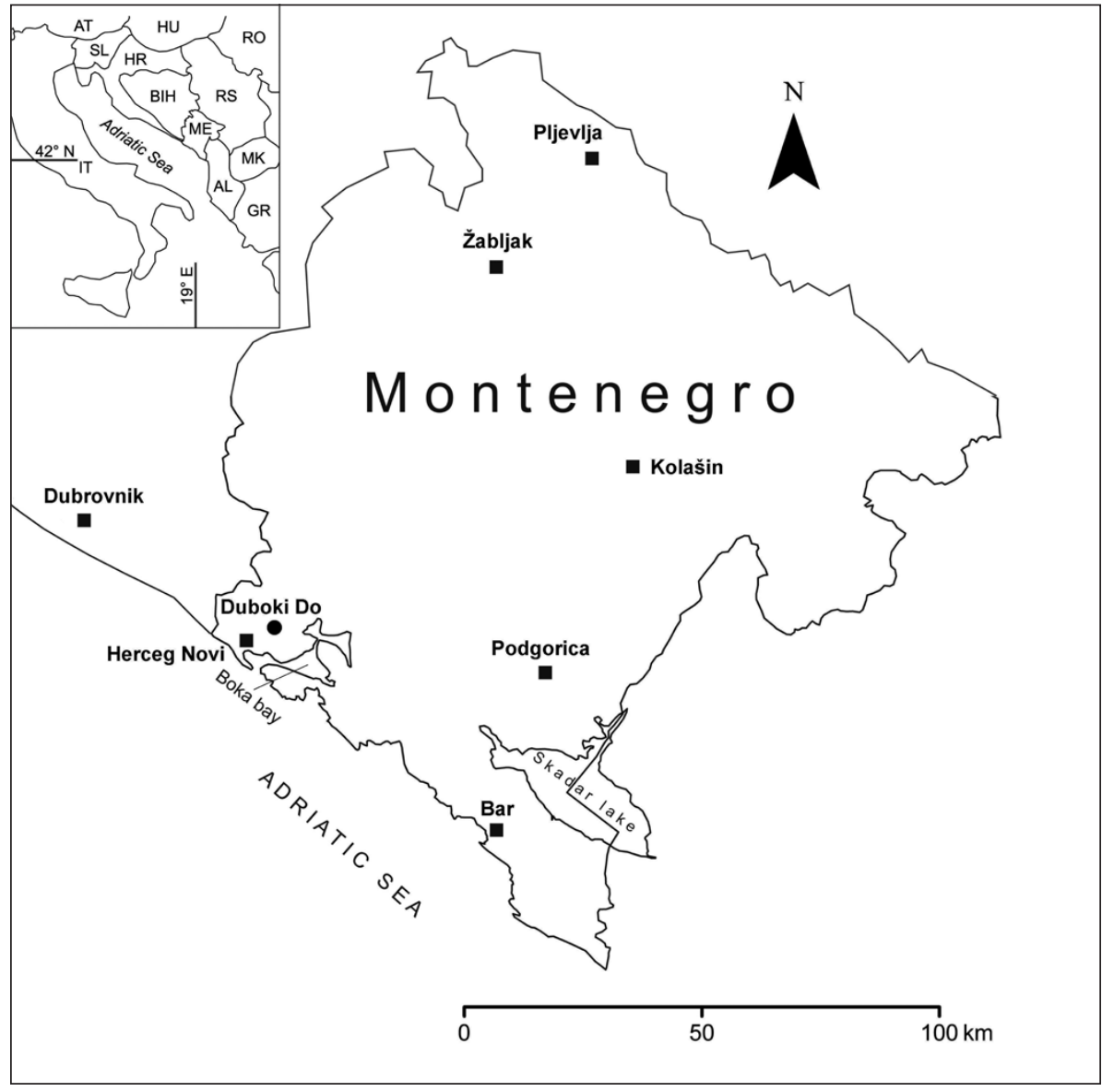

Figure 1: Map of Montenegro (ME) showing the localities where the precipitation has been collected and location of projected Duboki do landfill. 
barrier towards the springs. Generally, it is necessary to determine the recharge zones of the karstic springs used for water supply in this area, to investigate which of them are at risk of being contaminated by the planned landfill or other anthropogenic activities.

During previous investigations, an artificial tracer (uranine) was injected into the borehole B3 at Duboki Do. However, the tracer did not appear in any of the surrounding springs (Šućur, 2015; Doklestic, et al., 2015). It was assumed that the tracer went to submarine springs and that therefore the tracer was not noticed. Montenegrin largest submarine spring is the Sopot Spring, which is located around $11 \mathrm{~km}$ east of Duboki Do in the Risan Bay.

Stable isotope patterns in water can give information about the origin of the water, the catchment area, altitude etc. of a spring or water body, the reservoir size, the residence time and further information (Clark \& Fritz, 1997). The origin of water can be identified by comparison of the stable isotope patterns of the groundwater body and possible meteoric (or river-) origins. Stable isotopes in precipitation are influenced by several fractionation processes, the magnitude of which in temperate climates depends mainly on temperature and altitude (temperature and altitude effects, Dansgaard, 1964) and the distance from the coast (continent effect, Gat \& Gonfiantini, 1981). These result in typical isotope values and seasonal patterns for different catchment areas and allow the discrimination of water samples and therefore provide the basis for assessing the mean altitude of the catchment (Reischer et al., 2015).

Thus, using Isotope ratio mass spectrometry (IRMS) measurements could favor one of two selected hypotheses. To our knowledge this is the first study on isotope hydrology in Montenegro, besides some preliminary investigations by Horacek et al. (2019). Preliminary results have been published in Radulovic et al., 2019.

\section{LOCALITY, GEOLOGICAL AND HYDROGEOLOGICAL SETTING}

The landfill is planned at the high karst plateau northeast of Herceg Novi, at an altitude of $1,050 \mathrm{~m}$ a.s.l. (Figure 1). Herceg Novi is situated at the outer part of Boka bay (southwest Montenegro). The location Duboki Do is situated in a karst doline (sinkhole). Coordinates of the site are $42^{\circ} 29^{\prime} 56.73^{\prime \prime} \mathrm{N} ; 18^{\circ} 35^{\prime} 12.55^{\prime \prime} \mathrm{E}$.

Geological investigation of borehole B3 in the Duboki do doline showed a ca. $4 \mathrm{~m}$ thick layer of clayey soil in the above the bedrock. The subsoil geology of the Duboki do locality consists of carbonate rocks (Jurassic limestone and dolomite) (Antonijević et al., 1973; Mirković et al., 1985), which are characterized by high permeability, covering a wide area. The water table was reached at 11.6 $\mathrm{m}$ in the borehole B3 on $6^{\text {th }}$ December 2014. Impervious Flysh sediments extend along a narrow zone from Morinj bay on the east to the western border of the research area.

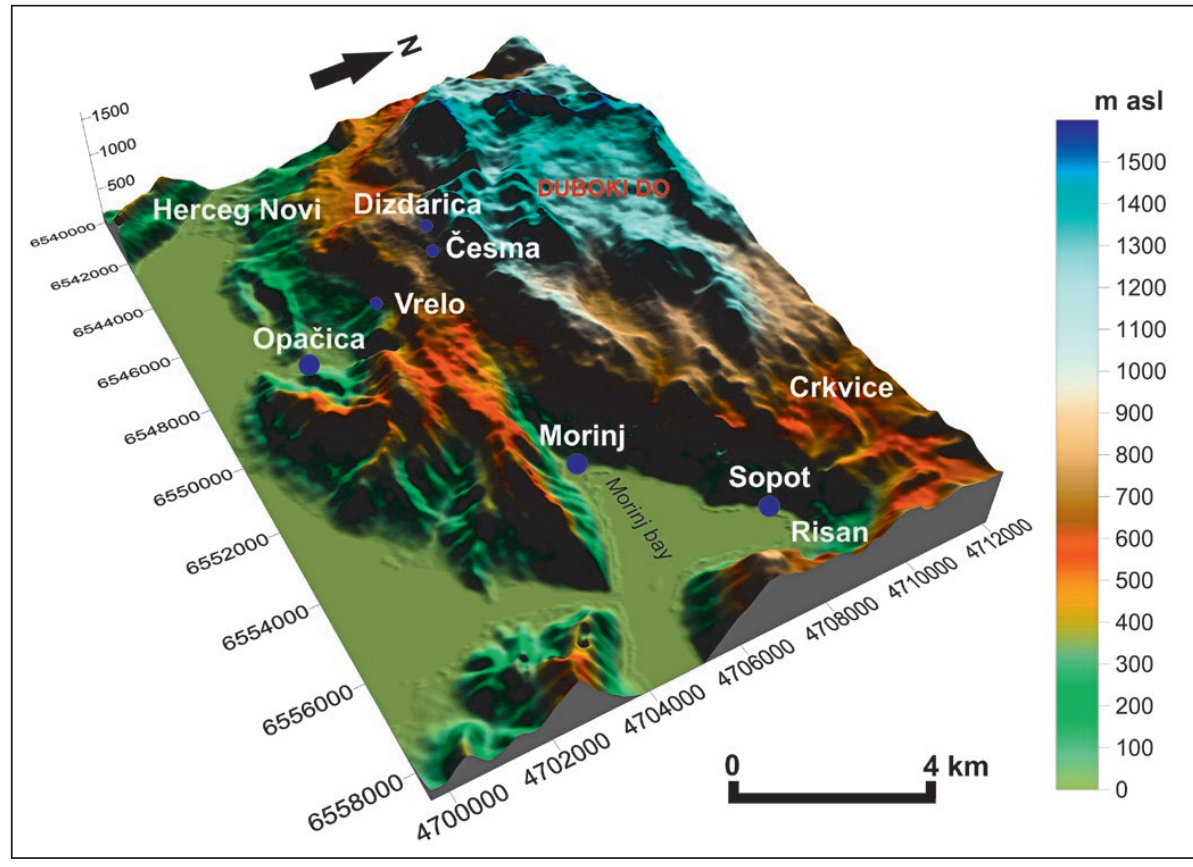

Figure 2: Digital elevation model of the wider area of Duboki do doline. The eastern tongue of the Morinj bay is the Risan bay (Risan), where the submarine Sopot spring is located close to the coast. "Herzeg Novi" and "Crkvice" indicate the location of these two towns. 


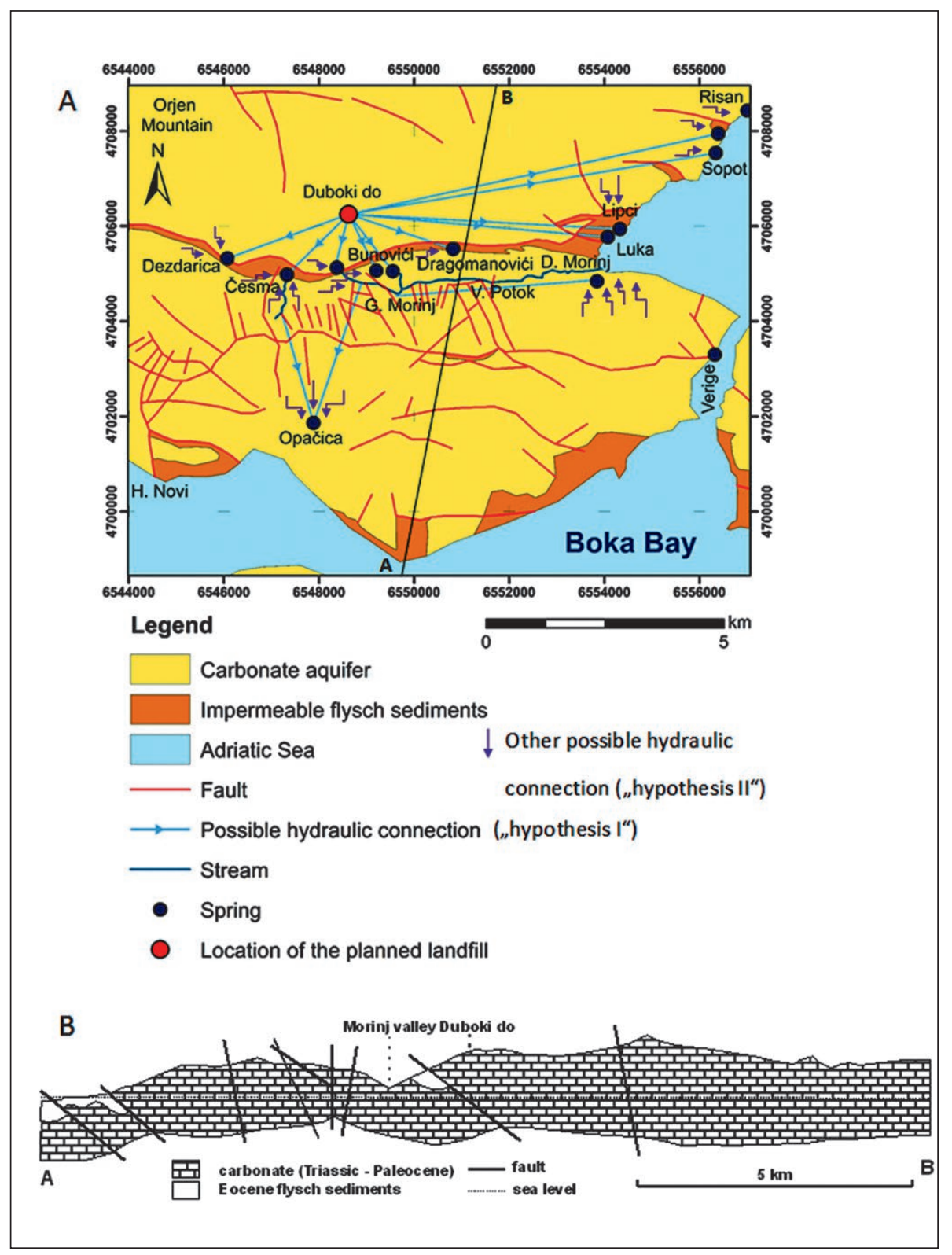

Figure 3: Map of possible groundwater flow directions (indicating the recharge areas of the spring for hypothesis I and II) from the location of landfill Duboki do, with a cross section depicting the simplified geological situation.

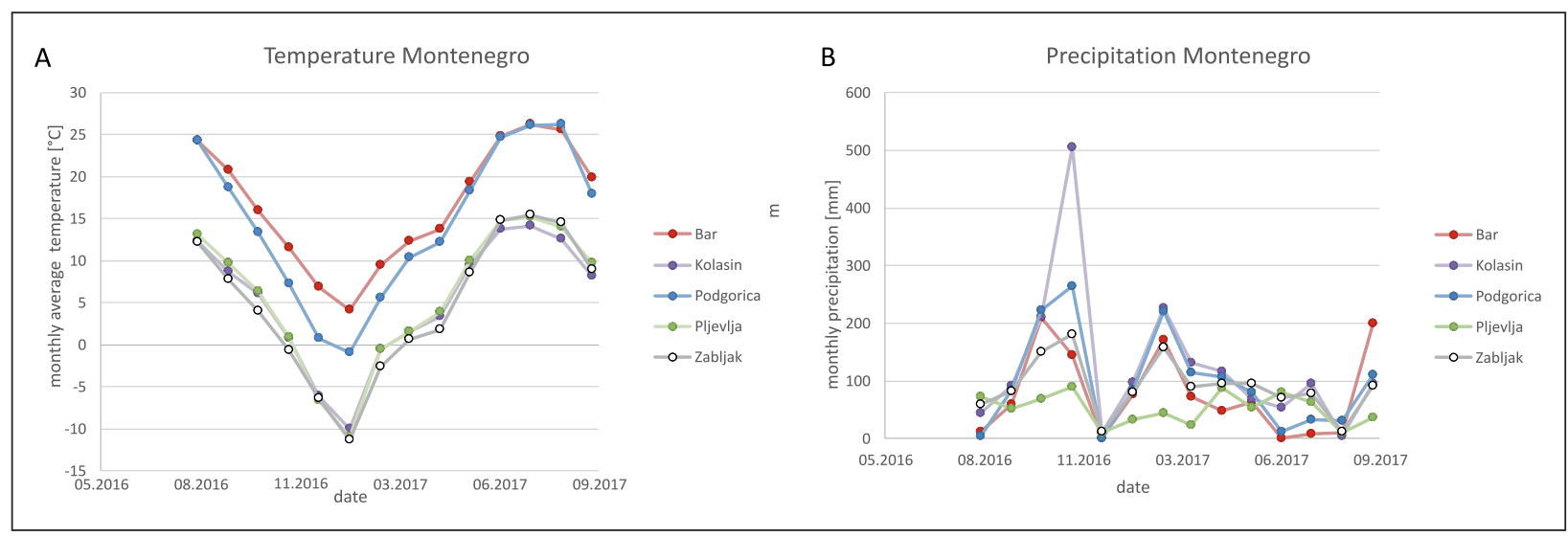

Figure 4: Temperature A) and precipitation B) data from the precipitation collection localities for the investigated period. 
Along this Flysch zone there are many small springs at higher altitudes (Figures 2, 3). Although the terrain generally is very permeable, the conditions of groundwater flow within a Karst aquifer are very complex. By the application of the conventional hydrologic methods in this terrain, it was not possible to reliably determine the recharge area of karstic springs (Šućur, 2015; Doklestic et al., 2015), nor to identify the groundwater flow directions from the location of landfill (Šućur, 2015; Doklestic et al., 2015).

\section{SAMPLING AND ANALYTICAL METHODS}

Precipitation water samples have been collected throughout one year (from September 2016 to September 2017) as monthly samples from the following localities: Bar (5 $\mathrm{m}$ a.s.l.), Podgorica (32 m a.s.l.), Kolašin (954 m a.s.l.), Žabljak (1,456 m a.s.l.) and Pljevlja (770 m a.s.l.), see Figure 1. There are not precipitation samples available for all months, as during some months there was no precipitation at some stations. Information about weather data (air temperature, precipitation) during the investigated period is shown in Figures 4A, B.

Spring samples have been collected in July 2017 from the following sources: Česma, Vrelo, Donji Morinj, Opačica (Zelenika).

The stable isotope composition of precipitation, surface and spring water samples were analysed using the isotope mass spectrometer Thermo Finnigan DeltaPlusXL equipped with automatic equilibration lines and the Picarro L1115-i Isotopic Liquid Water and Water Vapor Analyzer (laser spectroscopic analyser, CRDS) at the Austrian Institute of Technology (AIT) in Tulln. All results are reported as relative abundance $\left(\delta^{2} \mathrm{H}\right.$ and $\delta^{18} \mathrm{O}$, respectively) of the isotopes ${ }^{2} \mathrm{H}$ and ${ }^{18} \mathrm{O}$ in per mill (\%) with respect to the international standard VSMOW (Vienna Standard Mean Ocean Water). The accuracy of measurement is better than $\pm 1.0 \%$ or for $\delta^{2} \mathrm{H}$ and $\pm 0.1 \%$ o for $\delta^{18} \mathrm{O}$. Calibration of the mass spectrometer and CRDS was accomplished using VSMOW, GISP, and SLAP standards (Reischer et al., 2015).

\section{RESULTS}

Results are shown in Table 1 and Figures 5-7.

Precipitation from the coastal and lowland region (Bar, Podgorica) show significantly higher isotope values (Figure 5 and Figure 6) than the precipitation from the high-altitude hinterland localities (Kolašin, Žabljak), with Pljevlja station showing a "continental" pattern of low values in winter (similar to the high-altitude stations) and high values in summer (similar to the lowland stations). Annual averages from Bar are $-24.1 \%$ and $-3.5 \%$ for $\delta^{2} \mathrm{H}$ and $\delta^{18} \mathrm{O}$ isotope values respectively, from Podgorica $-26.4 \%$ and $-3.9 \%$, from Kolašin $-43.0 \%$ and $-6.6 \%$, from Žabljak $-44.7 \%$ and $-6.7 \%$ and from Pljevlja $-43.0 \%$ and $-5.7 \%$ or $\delta^{2} \mathrm{H}$ and $\delta^{18} \mathrm{O}$ isotope values, respectively (for our sampling period, without taking into account the monthly volumes). Differences in isotope values between low- and high hinterland sample stations seems to be largest during autumn and spring. The seasonal variation in isotope values, with elevated values in summer and low values in winter can be observed in the data as well.

One sample showing exceptionally high (and positive) $\mathrm{H}$ - and $\mathrm{O}$ - isotope values in summer from the Podgorica sampling site might belong to an individual pre- cipitation event or evaporation before sample collection, due to the elevated Deuterium excess-value, and is eliminated from the data set.

Results from the four springs investigated (Figure 7 , Table 1) give low isotope values around $-60 \%$ for hydrogen and lower than $-9 \%$ for oxygen isotopes. Most of the analyzed water samples (precipitation and spring water, Figure 7) lie close to the Global Meteoric Water Line (GMWL; Craig, 1961). The (summer) samples with the highest isotope values, however, show a trend towards the side right of the GMWL, which indicates significant influence of evaporation. The relationship between $\mathrm{d}^{2} \mathrm{H}$ and $\mathrm{d}^{18} \mathrm{O}$ is the deuterium excess (d), globally defined as $\mathrm{d}=\delta^{2} \mathrm{H}-8^{\star} \delta^{18} \mathrm{O}$ (Dansgaard, 1964) and adapted for Middle Europe (Austria) as $\mathrm{d}=\delta^{2} \mathrm{H}-7.88 \delta^{18} \mathrm{O}$ (Humer et al., 1995). Deuterium excess of spring and river water usually ranges from 9 to 13 (Reischer et al., 2015) and the value increases with altitude (Schotterer et al., 1993; Holko, 1995; Gonfiantini et al., 2001, Rank et al., 2016). Low values usually are a sign for partial evaporation of the water sample (Horvatincic et al., 2005). The uncertainty of the deuterium excess is \pm 1.3 (combined uncertainties of $\delta^{2} \mathrm{H}$ and $\delta^{18} \mathrm{O}$ measurements). 

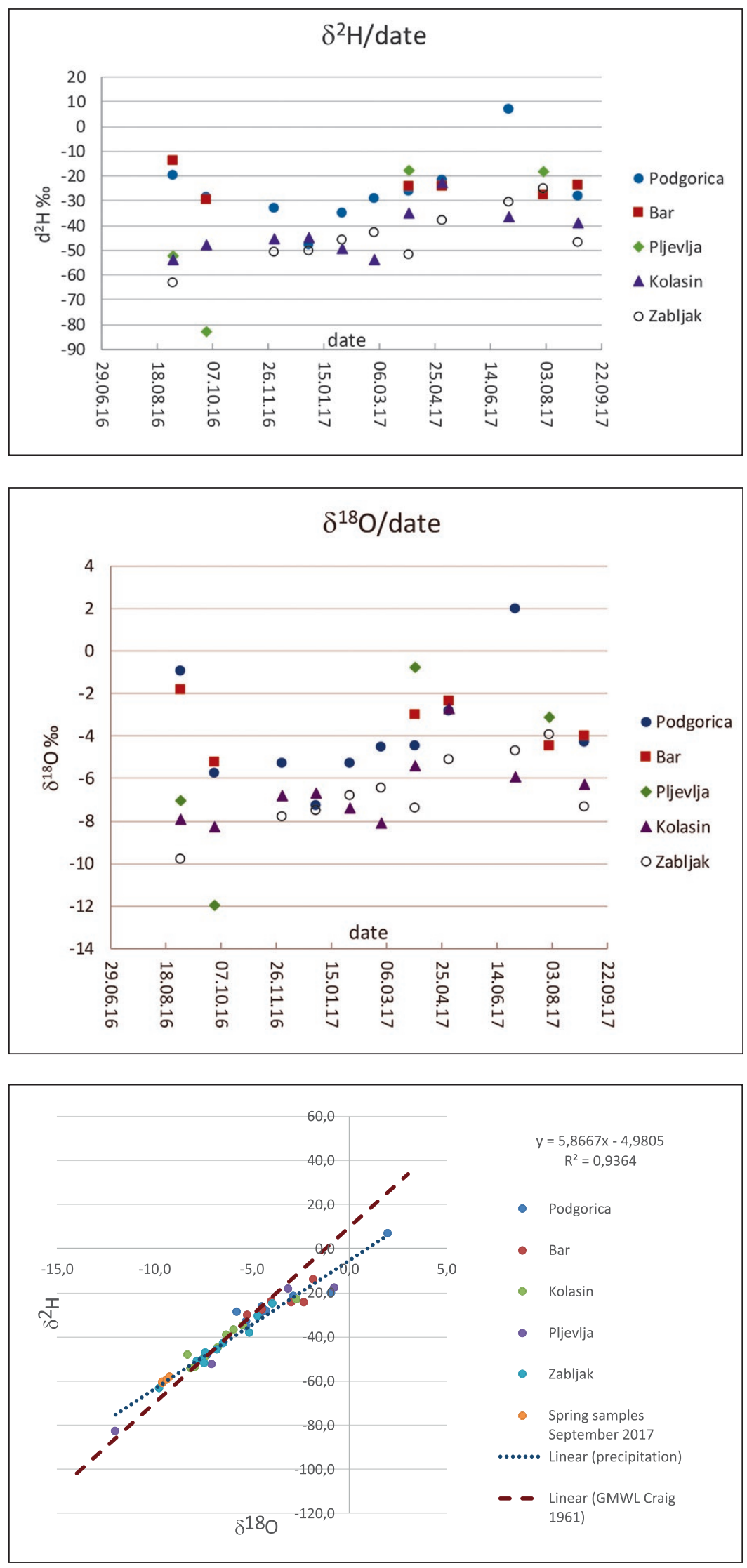

Figure 5: Diagram showing $d^{2} H$-isotope values in precipitation from different localities versus time.

Figure 6: Diagram showing $d^{18} \mathrm{O}$-isotope values in precipitation from different localities versus time.
Figure 7: Diagram showing $\delta^{2} \mathrm{H}$ and $\delta^{18} \mathrm{O}$ isotope values of all analyzed water samples (precipitation and spring water) together with linear equation (Linear) of precipitation samples and $R^{2}$, and with Global Meteoric Water Line (Linear (GMWL Craig, 1963)). Samples with highest isotope values dominantly plot on right side of GMWL and thus indicate evaporation effects. Spring water samples fit to regional water line (Linear (precipitation)). 
Table 1: $\delta^{2} H$ and $\delta^{18} \mathrm{O}$ isotope values and d-excess of analysed water samples (precipitation and spring water).

\begin{tabular}{|c|c|c|c|c|}
\hline Sampling locality & Sampling date & $\delta^{2} \mathrm{H}[\% \circ]$ vs.VSMOW & $\delta^{18} \mathrm{O}[\%$ ] vs.VSMOW & D-excess \\
\hline \multirow{6}{*}{ Bar } & Sep.16 & -14.2 & -1.8 & 0.3 \\
\hline & Oct.16 & -30.0 & -5.2 & 11.7 \\
\hline & Apr.17 & -24.4 & -3.0 & -0.5 \\
\hline & May 17 & -24.4 & -2.3 & -5.8 \\
\hline & Aug.17 & -27.7 & -4.4 & 7.8 \\
\hline & Sep.17 & -24.1 & -4.0 & 7.9 \\
\hline \multirow{10}{*}{ Kolasin } & Sep.16 & -54.1 & -7.9 & 9.3 \\
\hline & Oct.16 & -48.1 & -8.3 & 18.2 \\
\hline & Dec.16 & -45.4 & -6.8 & 8.8 \\
\hline & Jan.17 & -44.9 & -6.7 & 8.7 \\
\hline & Feb.17 & -49.5 & -7.4 & 9.8 \\
\hline & Mar.17 & -54.2 & -8.1 & 10.7 \\
\hline & Apr.17 & -35.0 & -5.4 & 8.4 \\
\hline & May 17 & -23.1 & -2.7 & -1.7 \\
\hline & Jul.17 & -36.6 & -5.9 & 10.7 \\
\hline & Sep.17 & -39.3 & -6.3 & 11.1 \\
\hline \multirow{4}{*}{ Pljevlja } & Sep.16 & -52.6 & -7.0 & 3.6 \\
\hline & Oct.16 & -82.9 & -12.0 & 12.9 \\
\hline & Apr.17 & -17.9 & -0.8 & -11.8 \\
\hline & Aug.17 & -18.4 & -3.1 & 6.6 \\
\hline \multirow{10}{*}{ Podgorica } & Sep.16 & -20.1 & -0.9 & -12.7 \\
\hline & Oct.16 & -28.7 & -5.8 & 17.5 \\
\hline & Dec.16 & -33.1 & -5.3 & 9.0 \\
\hline & Jan.17 & -48.2 & -7.3 & 9.8 \\
\hline & Feb.17 & -35.2 & -5.3 & 7.1 \\
\hline & Mar.17 & -29.2 & -4.5 & 7.0 \\
\hline & Apr.17 & -26.4 & -4.4 & 9.1 \\
\hline & May 17 & -21.8 & -2.8 & 0.9 \\
\hline & Jul.17 & 6.8 & 2.0 & -8.9 \\
\hline & Sep.17 & -28.2 & -4.3 & 5.8 \\
\hline \multirow{10}{*}{ Zabljak } & Sept. 2016 + Oct. 2016 & -63.6 & -9.8 & 14.5 \\
\hline & Dec.16 & -50.9 & -7.8 & 11.7 \\
\hline & Jan.17 & -50.5 & -7.5 & 9.7 \\
\hline & Feb.17 & -45.9 & -6.8 & 8.3 \\
\hline & Mar.17 & -43.2 & -6.4 & 8.2 \\
\hline & Apr.17 & -52.0 & -7.4 & 7.2 \\
\hline & May 17 & -38.2 & -5.1 & 2.8 \\
\hline & Jul.17 & -30.8 & -4.7 & 6.7 \\
\hline & Aug.17 & -25.1 & -3.9 & 6.3 \\
\hline & Sep.17 & -47.0 & -7.4 & 11.8 \\
\hline Spring Cesma & Sep.17 & -60.9 & -9.6 & 15.6 \\
\hline Spring Vrelo & Sep.17 & -60.6 & -9.6 & 15.9 \\
\hline Spring Donjia & Sep.17 & -59.4 & -9.4 & 15.6 \\
\hline Spring Zelenika & Sep.17 & -58.3 & -9.2 & 15.1 \\
\hline
\end{tabular}


The precipitation samples of the present study show a wide range of values from -12.7 to +18.2 . The lowest values are from samples from spring to autumn. They might have some evaporation component, and/ or represent individual single rain events, which might have very variable deuterium excess values (Rank and Papesch, 2005). The highest values (17.5 and 18.2) come from Podgorica and Kolašin October samples. The spring water samples have very similar $d$ values ranging from 15.1-15.9.

\section{DISCUSSION}

The precipitation isotope values from the coastal and lowland Bar and Podgorica sites are similar to published data from Dubrovnik (Horvatincic et al., 2005), the latter values are slightly more depleted, though. However, these published values are from an earlier period and thus not directly comparable, as more recent values are not available. Precipitation values from mountain collection sites (Kolašin, Žabljak) and far inland Montenegro (Pljevlja) show lower isotope values on average than the marine influenced lowland, as expected due to altitude and continent effects.

The $\delta^{2} \mathrm{H}$ and $\delta^{18} \mathrm{O}$ isotope values from the investigated springs are very low. They do not fit at all with the data from the coastal and lowland region (Bar and Podgorica) and are also lower than most of the precipitation data from the high-altitude hinterland, but do fit with their high-altitude winter precipitation values. Thus, most likely the water from the investigated springs originates from winter precipitation at higher altitudes. The catchment area(s) of these springs seem to dominantly receive precipitation during the winter period (as snow, based on the water isotope signatures of the investigated samples) and are supplied throughout the year with this winter precipitation dominated water, perhaps due to melting of the snow during a longer period from spring to early summer. Furthermore, the deuterium excess values of the four springs investigated, which are very similar, show very high values. The Mediterranean Sea is a landlocked marine water body where, especially in winter, continental air masses impinge on seawater under conditions of large humidity deficit, a strong temperature contrast between air and water and isotopic disequilibrium between the atmospheric moisture and the water body (Gat \& Dansgaard, 1972). Therefore winter precipitation originating from the Mediterranean Sea is characterized by distinctly higher d-excess values, reflecting the specific source conditions during water vapour formation.

The deuterium excess can be used to identify vapour source regions (Gat et al., 2003). The spring water samples have d-excess values ranging from 15.1-15.9 which indicates a water vapour source from the Mediterranean Sea during the winter months. Combined with the $\delta^{2} \mathrm{H}$ and $\delta^{18} \mathrm{O}$ isotope values the spring water samples are interpreted as coming from a high-altitude catchment and representing winter precipitation.

As all spring water samples are very similar, a common catchment area and similar to identical retention time for the springs investigated seems likely. An origin of the water of the investigated springs from the hinterland of the Morinj bay and thus the location of the catchment area(s) at lower (ca. $500 \mathrm{~m}$ a.s.l.) altitude is, based on our isotope results, very unlikely. Therefore, hypothesis II can be rejected and hypothesis I, assuming the high karst plateau of the wider Duboki do area/ region, is likely. However, due to the depleted isotope and the high $\mathrm{d}$-excess values, we want to introduce working hypothesis III, assuming the origin of the investigated spring water samples from a catchment area of even higher altitude than Duboki do. A possible area might be Orjen Mountain, several kilometers further inland to the North of Duboki do. Due to sampling problems spring water samples were only collected once in summer 2017. This limits the study to a one-point or snap-shot view of the situation, and thus there also is the possibility that hypothesis I still might be valid for other times of the year. Therefore, further studies investigating the spring water and precipitation from potential catchment areas over an at least one year interval are required to tackle this question. At present, an origin of the water of the springs nearby Duboki do from the planned land fill area cannot be ruled out.

This result has serious implications with respect to the municipal water supply utilizing springs around the future land fill. Once in operation, the landfill poses a potential and continuous threat to the quality and innocuousness of the springs and their water. To prevent the supply with contaminated tap water (and thus also the contamination of the water line), the springs used for municipal water supply need to be closely and constantly monitored for their water quality, to detect any decrease in quality and potential health threat in time. If the landfill becomes leak it might contaminate the springs. Depending on the severity of the leakage and dilution the spring water used for tap water supply will require disinfection, filtration and maybe additional 
processes (e.g. dilution) to maintain an acceptable water quality. Water contamination of springs not used for water supply might not directly negatively impact on humans but will negatively influence the ecosystem and nature.

\section{CONCLUSIONS}

To solve the pressing question whether the construction of a new waste dump north of Herzeg Novi at ca. $1000 \mathrm{~m}$ altitude in a sinkhole (named Duboki do) in a karst mountainous area poses a threat for nearby karst water springs due to the risk of contamination, a stable isotope investigation of spring and precipitation water samples has been performed. The stable isotope results of samples from springs in the Herceg Novi region, compared with isotope data of precipitation from various stations in Montenegro, demonstrate an origin of the spring water samples from a high-altitude catch- ment area receiving mainly winter precipitation, as the Duboki do locality. Thus, an origin from the Duboki do area cannot be ruled out and is the likely one of the two presented working hypotheses, with the other hypothesis of an origin of the spring water from a lower altitude area seeming much less probable. However, as an isotope record over a longer period for the investigated springs has not been produced, uncertainties remain, if the springs might be fed from a catchment area of even higher altitude, and thus further studies covering a longer sampling period are necessary.

\section{ACKNOWLEDGMENTS}

Partial funding by a bilateral grant (ME 05/2015-16) of the Österreichische Austauschdienst (ÖAD) to M. Hor- acek and the Montenegrin Ministry of Science (Ministarstvo nauke) to D. Jancic is thankfully acknowledged.

\section{REFERENCES}

Antonijević, R., Pavić, A., Karović, J., 1973. Basic geological map 1:100,000, "Kotor" and "Budva" sheets (in Serbian). Federal Geological Survey, Belgrade [Map].

Clark, I.D., Fritz, P., 1997. Environmental Isotopes in Hydrogeology. Lewis Publishers, Boca Raton, 328 pp

Craig, H., 1961. Isotopic variations in meteoric waters. Science, 133: 1702-1703. http://dx.doi. org/10.2307/1708089

Dansgaard, W., 1964. Stable isotopes in precipitation. Tellus, 16(4): 436-268. https://doi.org/10.3402/tellusa.v16i4.8993

Doklestić, O., Šućur, M., Radulović, M.M., 2015. Impact of sanitary landfill "Duboki do" on underground waters. In: Djukić A. (Ed.), Water 2015, the $44^{\text {th }}$ Annual Conference of the Serbian Water Pollution Control Society, Kopaonik, Serbia, $2^{\text {nd }}-4^{\text {th }}$ June 2015 , pp 249-256. UDK: 502.51 (282.02):628.468 (497.16)

Dubljević, V., 2001. Hydrogeological characteristics of
Boka Bay (in Serbian) [Master thesis]. University of Belgrade, 198 pp.

Gat, J.R., Dansgaard, W., 1972. Stable isotopes survey of the freshwater occurrences in Israel and the Jordan Rift Valley. Journal of Hydrology, 16(3): 177-211. https://doi.org/10.1016/0022-1694(72)90052-2

Gat, J.R, Gonfiantini, R., (Eds.), 1981. Stable Isotope Hydrology. Deuterium and Oxygen-18 in the Water Cycle. IAEA Technical Report series 210. International Atomic Energy Agency (IAEA), 338 pp.

Gat, J.R., Klein, B., Kushnir, Y., Roether, W., Wernli, H., Yam, R., Shemesh, A., 2003. Isotope composition of air moisture over the Mediterranean Sea: an index of the air-sea interaction pattern. Tellus B, 55(5): 953965. https://doi.org/10.3402/tellusb.v55i5.16395

Gonfiantini, R., Roche, M.A., Olivry, J.C., Fontes, J.C., Zuppi, G.M., 2001. The altitude effect on the isotopic composition of tropical rains. Chemical Geol- 
ogy, 181(1-4): 147-167. http://dx.doi.org/10.1016/ S0009-2541(01)00279-0

Holko, L., 1995. Stable environmental isotopes of $18 \mathrm{O}$ and $2 \mathrm{H}$ in hydrological research of mountainous catchment. Journal of Hydrology and Hydromechanics, 43(4):249-274.

Horacek, M., Radulovic, M.,Wyhlidal, S., Misurovic, A., Jung, M., 2019. Investigating catchment areas of karst springs in Montenegro: Isotope-hydrological pilot studies. Geoloski Glasnik, 9: 129-143.

Horvatinčić, N., Krajcar Bronić, I., Barešić, J., Obelić, B., Vidič, S., 2005. Tritium and stable isotope distribution in the Atmosphere at the coastal region of Croatia. [Technical report, IAEA-TECDOC-1453]. International Atomic Energy Agency (IAEA), pp. 230. ISBN 92-0-105305-3, ISSN 1011-4289.

Humer, G., Rank, D., Trimborn, P., Stichler, W., 1995. Niederschlags-Isotopenmessnetz Österreich. Monographie, 52. Umweltbundesamt, Vienna, 86 pp.

IJC (Institut Jaroslav Cerni), 2001. Water master plan of Montenegro. Government of Montenegro, Podgorica, $544 \mathrm{pp}$.

Marić, M., 1997. Basic hydrogeological map of SRY 1:100,000, "Kotor" and "Budva" sheets (in Serbian). Geological Survey of Montenegro [Map].

Mirković, M., Žvaljević, M., Đokić, V., Perović, Z., Kalezić, M., Pajović, M., 1985. Geological map of Montenegro 1:200,000. The Republic Self Managing Community of Interest for Geological Exploration of Montenegro [Map].

Radulović, M., 1995. Report on hydrogeological investigations of Kuti Valley and Opačica water source (Herceg Novi) (in Serbian). Geological Survey of Montenegro, Podgorica, $30 \mathrm{pp}$.

Radulović, M., 2000. Karst hydrogeology of Montenegro (in Serbian). Geological Survey of Montenegro, Podgorica, $271 \mathrm{pp}$.

Radulović, M., Radulović, V., 2004, Hydrogeological map of Montenegro 1:200,000 (in Serbian). Geological Survey of Montenegro [Map].
Radulovic, M., Wyhlidal, S., Horacek, M., 2019. Potential threat of new public landfill on tap water sources in Western Montenegro. Geophysical Research Abstracts, Vol. 21, EGU2019-17737-1, 2019. EGU General Assembly 2019, Vienna.

Rank, D., Papesch, W., 2005. Isotopic composition of precipitation in Austria in relation to air circulation patterns and climate. In: Isotopic composition of precipitation in the Mediterranean Basin in relation to air circulation patterns and climate [Technical report, IAEA-TECDOC-1453]. International Atomic Energy Agency (IAEA), pp. 230. ISBN 920-105305-3, ISSN 1011-4289.

Rank, D., Wyhlidal, S., Heiss, G., Papesch, W., Schott, K., 2016. Arsenal environmental-isotope laboratories 1964-2010 - more than 45 years production / application / interpretation of basic isotope-hydrological data for Central Europe. Austrian Journal of Earth Sciences, 109(1), p. 4-28. DOI: 10.17738/ ajes.2016.0001

Reischer, M., Bichler, B., Spötl, C., Höfer-Öllinger, G., Wyhlidal, S., 2015. Karst hydrogeology of the Untersberg massif and its interaction with the porous aquifer in the adjacent Salzburg Basin. Austrian Journal of Earth Sciences, 108(2): 68-81. http:// dx.doi.org/10.17738/ajes.2015.0014

Schotterer, U., Fröhlich, K., Stichler, W., Trimborn, P., 1993. Temporal variation of $18 \mathrm{O}$ and deuterium excess in precipitation, river and spring waters in Alpine regions of Switzerland. In: Isotope Techniques in the study of past and current environmental changes in the hydrosphere and the atmosphere. IAEA-SM-329. International Atomic Energy Agency (IAEA), Vienna, pp. 642.

Šućur, M., 2015. Report on detailed geotechnical investigations of the location of planned landfill "Duboki Do" (Herceg Novi) (in Serbian) [Report]. Geotehnika Ltd., 25 pp. 